\title{
The Attitudes of Nurses in the Hospital toward Vulnerable People
}

\author{
Sri Mulyani ${ }^{1 *}$ (D) Patricia Suti Lasmani ${ }^{2}$, Azam David Saifullah $^{1}$ (D), Afifah Fawadya ${ }^{3}$ (D) Aisyah Iffah $^{3}$ (D), Shania Pramestya ${ }^{3}$ (D) \\ ${ }^{1}$ Department of Mental Health and Community Nursing, Faculty of Medicine, Public Health and Nursing, Universitas Gadjah \\ Mada, Yogyakarta, Indonesia; ${ }^{2}$ Nursing Committee, RSUP Dr. Sardjito General Hospital, Yogyakarta, Indonesia; ${ }^{3}$ Department \\ of Public Health and Nursing, Students of School of Nursing, Faculty of Medicine, Universitas Gadjah Mada, Yogyakarta, \\ Indonesia
}

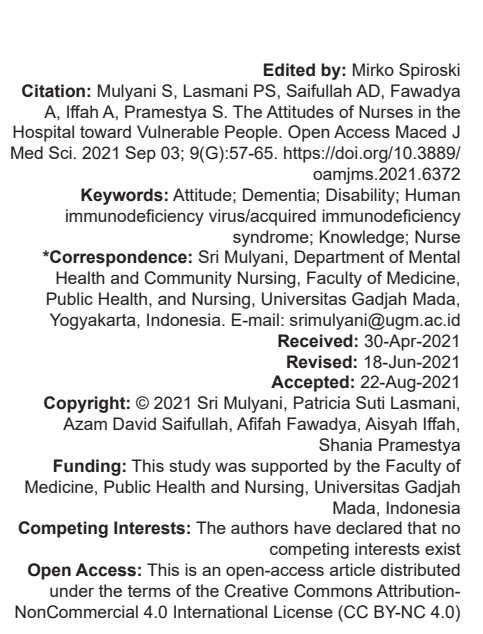

\section{Introduction}

Vulnerable people are at higher risk for poor health as a result of the barriers that prevent access to the resources of social, economic, political, and environmental support, as well as limitations due to an illness or disability condition [1]. The increasing number of vulnerable people can have long-term effects for themselves, their families, the environment, and health care workers [2]. Several groups have some vulnerabilities particularly people with disabilities (PwDs), people with dementia (PWD), and people living with HIVIAIDS (PLWHA). As many as 1 billion people live with disabilities [3], while as many as 50 million people in the world are PWD [4], and 37.9 million people have HIVIAIDS [5].

Discrimination against people who are vulnerable in health services often occurs due to lack of knowledge, experience, and the presence of stigma [6]. Nurses are the largest group of health workers and regularly meet with patients [7]. Nurses must be competent in terms of knowledge and skills when providing healthcare [8]. The satisfaction and comfort of patients in healthcare will determine whether a patient will do the treatment again or not [9].

Earlier studies on attitudes toward vulnerable people have revealed different results. Nurses tend to display negative attitudes on PwDs [7], [10], [11]. The majority of Indian nurses hold a positive attitude toward PWD because of the perception that caring for dementia patients is beneficial [12]. The discriminatory attitudes of nurses against PLWHA are inspired by religion, community stigma, low levels of knowledge, fear of contagion, as well as the lack of experience, and training in caring for patients with HIVIAIDS [13].

Nurses' attitudes are able to influence the quality of health care. Lack of knowledge contributes to the negative attitudes and discriminatory performance by nurses [14]. Hence, a study that measures nurses' attitudes toward vulnerable people is very relevant. 


\section{Research Methods}

This quantitative study used a cross-sectional design which aimed to identify the attitudes of nurses in the hospital and the factors that influence it. This study was conducted in January-February 2021 with 386 people selected using the consecutive sampling technique. The inclusion criteria were: Nurses who are still actively working in Dr. Sardjito Hospital for at least one year, a permanent employee, with a minimal 3-year diploma (D3). The exclusion criteria were: An internship nurse. Researchers want to examine the attitude of nurses in Sardjito Hospital. Internship nurses were excluded since they are not permanently working at Sardjito Hospital. This research gained ethical approval from the Medical and Health Research Ethics Committee of the Medical Faculty Universitas Gadjah Mada number KE/FK/0352/EC/2020 and permission from Dr. Sardjito Hospital.

Researchers sent a Google Form link for nurses to fill out voluntarily through a hospital chat group. Furthermore, the researcher sent reminders once a week for 1 month. Researchers provided pulses gifts for 100 respondents randomly. Participants' names and telephone numbers were used only for shuffling participant that got the rewards.

Data were analyzed using SPSS for univariate analysis utilizing frequency, percentage, median, mean, standard deviation (SD), and minimum-maximum (minmax) values. Bivariate analysis was conducted using the Spearman Rank Test, Mann-Whitney Test, and Kruskal-Wallis Test. The result is significant if $p<0.050$. Researchers used a demographic questionnaire, as well as nurses' knowledge and attitudes toward vulnerable people (PwDs, PLWD, and PLWHA). The researcher carried out anonymization by omitting the names and telephone numbers of participants during data processing, and not including them in the results of the study.

The attitudes of nurses toward PwDs were measured using Attitude Toward Disabled Person Scale Form O (ATDP-O) questionnaire. The ATDP-O questionnaire was developed by Yuker et al., 1970 [15]. This questionnaire consists of 19 items. This questionnaire has been translated into Indonesian language. ATDP-O in Indonesian language has a good reliability with Cronbach's alpha $=0.645$ [16]. The ATDP-O questionnaires used the 6 Likert Scale (-3 to +3 ) with minimum score 0 and maximum score 117 with Constanta of 60.

The attitudes of nurses toward PWD were measured using the Dementia Attitude Scale (DAS) questionnaire. The DAS questionnaire was developed by O'Connor and McFadden in 2010 [17]. This questionnaire consists of 20 items. This questionnaire has been translated into Indonesian language. DAS in Indonesian language have a good reliability with
Cronbach's alpha $=0.754$ [18]. The DAS questionnaires used the 7 Likert Scale (1-7) with minimum score 0 and maximum score 140.

The attitudes of nurses toward PLWHA were measured using the AIDS Attitude Scale (AAS) questionnaire. The AAS questionnaire was developed by Froman and Owen in 1997 [19]. This questionnaire consists of 20 items. This questionnaire has been translated into Indonesian language. AAS in Indonesian language has a good reliability with Cronbach's alpha = 0.726 [20]. The AAS questionnaires used the 6 Likert Scale (1-6) with minimum score -5 and maximum score +5 .

The knowledge of nurses towards PwDs was measured using the Self-Administered Questionnaire about Knowledge (SAQ-K) (Knowledge of Healthcare Professionals about Person with Disabilities). The SAQ-K questionnaire was developed by Iftikhar et al., in 2019 [21]. This questionnaire consists of 23 items. This questionnaire has been translated into Indonesian language. SAQ-K in Indonesian language has a good reliability with KR-20 $=0.693$. The SAQ-K questionnaires used the Guttman scale (yes, no, and do not know) with minimum score 0 and maximum score 23.

The knowledge of nurses towards PWD was measured using the Dementia Knowledge Assessment Scale (DKAS) questionnaire. The DKAS questionnaire was developed by Annear et al., in 2014 [22]. This questionnaire consists of 25 items. This questionnaire has been translated into Indonesian language. DKAS in Indonesian language has a good reliability with Cronbach's alpha $=0.674$ [18]. The DKAS questionnaires used the 5 Likert Scale (1-5) with minimum score 0 and maximum score 50 .

The knowledge of nurses toward PLWHA was measured using HIV-Knowledge Questionnaire-18 (HIV-KQ-18). The HIV-KQ-18 questionnaire was developed by Carey and Schroder in 2002 [23]. This questionnaire consists of 18 items. This questionnaire has been translated into Indonesian language. HIV-KQ-18 in Indonesian language has a good reliability with Cronbach's alpha $=0.665$ [20]. The HIV-KQ-18 questionnaires used the Guttman scale (yes, no, and do not know) with minimum score 0 and maximum score 18.

\section{Research Results}

\section{Characteristics of research respondents}

Respondents in this study amounted to 386 nurses. Characteristics of respondents in this study, including age, gender, educational background, family, interaction, and experience history as well as previous education or training in disability, dementia, 
and HIVIAIDS. The level of education of nurses in Indonesia is divided into diploma (D3 and D4), Bachelor (S1), master (S2), and doctorate (Table 1). Knowledge of dementia was presented using mean, since the data were normally distributed, meanwhile knowledge of disability and HIVIAIDS were presented using median because the data were not normally distributed.

Table 1: Characteristics of nurses $(n=386)$

\begin{tabular}{|c|c|c|c|c|}
\hline Characteristic & $\begin{array}{l}\text { Frequency } \\
\text { (n) }\end{array}$ & Percentage & Mean (SD) or Median & Min-Max \\
\hline \multicolumn{5}{|l|}{ Knowledge } \\
\hline Disability & & & 19 & $5-23$ \\
\hline Dementia & & & $23.52(7.93)$ & $0-46$ \\
\hline HIVIAIDS & & & 13 & $0-18$ \\
\hline Age & & & $39.560(8.76)$ & $23.00-58.00$ \\
\hline \multicolumn{5}{|l|}{ Gender } \\
\hline Male & 81 & 21.00 & & \\
\hline Female & 305 & 79.00 & & \\
\hline \multicolumn{5}{|c|}{ Education Background } \\
\hline D3 & 240 & 62.20 & & \\
\hline D4 & 12 & 3.10 & & \\
\hline $\mathrm{s} 1$ & 128 & 33.20 & & \\
\hline S2 & 6 & 1.60 & & \\
\hline \multicolumn{5}{|c|}{ History of Family } \\
\hline Disability & 9 & 2.30 & & \\
\hline Dementia & 23 & 6.00 & & \\
\hline \multicolumn{5}{|c|}{ History of Interacting } \\
\hline Disability & 115 & 29.80 & & \\
\hline Dementia & 123 & 31.90 & & \\
\hline HIV/AIDS & 204 & 52.80 & & \\
\hline \multicolumn{5}{|c|}{ Caring Experience } \\
\hline Disability & 114 & 29.50 & & \\
\hline Dementia & 141 & 36.50 & & \\
\hline HIV/AIDS & 264 & 68.40 & & \\
\hline \multicolumn{5}{|c|}{ Education or Training } \\
\hline Disability & 6 & 1.60 & & \\
\hline Dementia & 12 & 3.10 & & \\
\hline HIVIAIDS & 59 & 15.30 & & \\
\hline
\end{tabular}

\section{Attitude of nurses towards vulnerable \\ people}

The attitude data of nurses toward vulnerable people were not normally distributed after the Kolmogorov-Smirnov test was used. The result showed that $\mathrm{p}$ of ATDP-O $=0.000$, $\mathrm{p}$ of DAS $=0.041$, and $\mathrm{p}$ of AAS $=0.00$. Data were normally distributed if $p>0.050$ (Table 2). Therefore, bivariate statistical analysis was processed with non-parametric methods, namely, the Spearman Rank, Mann-Whitney, and Kruskal-Wallis tests (Table 3 ).

Table 2: Score of attitudes towards vulnerable people with characteristics of nurses $(n=386)$

\begin{tabular}{lll}
\hline Variable & Median & Min-Max \\
\hline Attitudes toward PwDs & 54 & $29-87$ \\
Attitudes toward PWD & 102 & $60-136$ \\
Attitudes toward PLWHA & -0.65 & $-1.90-1.20$ \\
\hline PwDs: People with disabilities, PWD: People with dementia, PLWHA: People living with HIV/AIDS (PLWHA).
\end{tabular}

\section{Factors related to nurse's attitude on vulnerable people}

Nurses' attitude toward vulnerable people were analyzed based on their demographic characteristic factors using non-parametric statistics for PwDs (Table 3), PWD (Tables 4 and 5), and PLWHA (Table 6). The results for PwDs showed that knowledge was statistically significant in affecting attitude towards- disabilities ( $p=0.033$ ). Furthermore, education background, history of interaction, and caring experience were also significant in affecting nurses' attitude on vulnerable people $(p=0.042, p=0.000$, p =.001) (Table 3).

Table 3: Bivariate analysis of score of attitudes toward PwDs with the characteristics of nurses $(n=386)$

\begin{tabular}{|c|c|c|c|c|c|}
\hline \multirow[t]{2}{*}{ Characteristics } & \multicolumn{5}{|c|}{ Attitude towards PwDs } \\
\hline & Median (Min-Max) & Statistic test & Score & df & $\mathrm{p}$-value \\
\hline Knowledge of PwDs & & rs test & 0.11 & - & $0.033^{*}$ \\
\hline Age & & rs test & -0.02 & - & 0.730 \\
\hline Gender & & U-test & 11736.00 & - & 0.490 \\
\hline Man & $54(29-80)$ & & & & \\
\hline Woman & $54(30-87)$ & & & & \\
\hline Education Background & & H-test & 8.22 & 3 & $0.042^{*}$ \\
\hline D3 & $53(29-87)$ & & & & \\
\hline D4 & $50.50(39-74)$ & & & & \\
\hline S1 & $56(31-82)$ & & & & \\
\hline S2 & $64.50(52-76)$ & & & & \\
\hline History of Family & & $\mathrm{H}$-test & 1249.0 & - & 0.176 \\
\hline Yes & $59(46-74)$ & & & & \\
\hline No & $54(29-87)$ & & & & \\
\hline History of Interaction & & U-test & 11055.0 & - & $0.000^{*}$ \\
\hline Yes & $58(33-82)$ & & & & \\
\hline No & $52(29-87)$ & & & & \\
\hline Caring Experience & & U-test & 12323.50 & - & $0.001^{*}$ \\
\hline Yes & $56.50(32-82)$ & & & & \\
\hline No & $52(29-87)$ & & & & \\
\hline Education or Training & & & & & \\
\hline Yes & $52.50(38-71)$ & U-test & 1085.50 & - & 0.841 \\
\hline No & $54(29-87)$ & & & & \\
\hline
\end{tabular}

Since the education background groups were signed to attitude toward disabilities; therefore, post hoc analysis was conducted using Mann-Whitney test to find out which group of education have differences between groups (Table 4).

Table 4: Post hoc analysis of score of attitudes toward PwDs with education level of nurses $(n=386)$

\begin{tabular}{|c|c|c|c|c|}
\hline \multirow[t]{13}{*}{$\begin{array}{l}\text { Score of attitudes of nurses toward } \\
\text { PwDs }\end{array}$} & Education Background & $\mathrm{N}$ & Mean Rank & $p$ value \\
\hline & D3 & 240 & 126.83 & 0.745 \\
\hline & D4 & 12 & 119.83 & \\
\hline & D3 & 240 & 176.48 & $0.048^{*}$ \\
\hline & S1 & 128 & 199.54 & \\
\hline & D3 & 240 & 121.96 & $0.032^{\star}$ \\
\hline & S2 & 6 & 185.08 & \\
\hline & D4 & 12 & 57.46 & 0.244 \\
\hline & S1 & 128 & 71.72 & \\
\hline & D4 & 12 & 7.670 & $0.039^{*}$ \\
\hline & S2 & 6 & 13.17 & \\
\hline & S1 & 128 & 66.42 & 0.137 \\
\hline & S2 & 6 & 90.50 & \\
\hline
\end{tabular}

Based on the results of Table 4, it can be interpreted that there are differences in attitudes toward PwDs between education background groups of D3 and S1 $(p=0.048)$, between D3 and S2 ( $p=0.032)$, and between D4 and S2 ( $p=0.039)$.

The results of PWD showed that knowledge were statistically significant in affecting attitude toward dementia ( $p=0.000)$. Furthermore, age, history of interaction, history of the family, caring experience, and education/training were also significant in affecting nurses attitude on PWD $(p=0.005, p=0.013, p=0.000$, $p=0.000$, and $p=0.000$ ) (Table 5).

In addition, nurses' attitude toward PLWHA revealed that knowledge were statistically significant in affecting attitude towards HIVIAIDS ( $p=0.000)$. Furthermore, age, history of interaction, caring experience, and education/training were also 
Table 5: Bivariate analysis of score of attitudes toward PWD with the characteristics of nurses $(n=386)$

\begin{tabular}{|c|c|c|c|c|c|}
\hline \multirow[t]{2}{*}{ Characteristics } & \multicolumn{5}{|c|}{ Attitude toward PWD } \\
\hline & Median (Min-Max) & Statistic test & Score & df & $\mathrm{p}$-value \\
\hline Knowledge of PWD & & rs test & 0.567 & - & $0.000^{*}$ \\
\hline Age & & rs test & 0.141 & - & $0.005^{*}$ \\
\hline \multicolumn{6}{|l|}{ Gender } \\
\hline Man & $99(60-136)$ & U-test & 11289.50 & - & 0.234 \\
\hline Woman & $102(71-132)$ & & & & \\
\hline \multicolumn{6}{|c|}{ Education Background } \\
\hline D3 & $101.50(71-136)$ & H-test & 5.99 & 3 & 0.112 \\
\hline D4 & $102.50(60-116)$ & & & & \\
\hline S1 & $101.50(73-131)$ & & & & \\
\hline S2 & $115(103-131)$ & & & & \\
\hline \multicolumn{6}{|l|}{ History of Family } \\
\hline Yes & $108(79-130)$ & H-test & 2888.50 & - & $0.013^{*}$ \\
\hline No & $101(60-136)$ & & & & \\
\hline \multicolumn{6}{|l|}{ History of Interaction } \\
\hline Yes & $108(78-136)$ & U-test & 11441.00 & - & $0.000^{*}$ \\
\hline No & $99(60-131)$ & & & & \\
\hline \multicolumn{6}{|l|}{ Caring Experience } \\
\hline Yes & $108(78-136)$ & U-test & 11794.00 & - & $0.000^{*}$ \\
\hline No & $98(60-136)$ & & & & \\
\hline \multicolumn{6}{|l|}{ Education or Training } \\
\hline Yes & $116(103-130)$ & U-test & 788.50 & - & $0.000^{*}$ \\
\hline No & $101(60-136)$ & & & & \\
\hline
\end{tabular}

Wallis tests, PWD: People with dementia.

significant in affecting nurses attitude on vulnerable people $(p=0.007, p=0.003, p=0.050$, and $p=0.011)$ (Table 6).

Table 6: Bivariate analysis of score of attitudes toward PLWHA with the characteristics of nurses $(n=386)$

\begin{tabular}{|c|c|c|c|c|c|}
\hline \multirow[t]{2}{*}{ Characteristics } & \multicolumn{5}{|c|}{ Attitude towards PLWHA } \\
\hline & Median (Min-Max) & Statistic test & Score & df & p-value \\
\hline Knowledge of PLWHA & & rs test & 0.34 & - & $0.000^{*}$ \\
\hline Age & & rs test & 0.14 & - & $0.007^{*}$ \\
\hline \multicolumn{6}{|l|}{ Gender } \\
\hline Man & $-0.65(-1.90-1.20)$ & U-test & 11684.50 & - & 0.454 \\
\hline Woman & $-0.70(-1.65-1.15)$ & & & & \\
\hline \multicolumn{6}{|l|}{ Education Background } \\
\hline D3 & $-0.68(-1.90-1.20)$ & $\mathrm{H}$-test & 6.82 & 3 & 0.078 \\
\hline D4 & $-0.58(-0.95-0.25)$ & & & & \\
\hline s1 & $-0.65(-1.35-1.15)$ & & & & \\
\hline S2 & $-0.15(-0.70-0.35)$ & & & & \\
\hline \multicolumn{6}{|l|}{ History of Interaction } \\
\hline Yes & $-0.60(-1.40-1.10)$ & U-test & 15261.50 & - & $0.003^{*}$ \\
\hline No & $-0.70(-1.90-1.20)$ & & & & \\
\hline \multicolumn{6}{|l|}{ Caring Experience } \\
\hline Yes & $-0.65(-1.55-1.15)$ & U-test & 14109.50 & - & $0.050^{*}$ \\
\hline No & $-0.70(-1.90-1.20)$ & & & & \\
\hline \multicolumn{6}{|l|}{ Education or Training } \\
\hline Yes & $-0.55(-1.30-1.15)$ & U-test & 7638.00 & - & $0.011^{*}$ \\
\hline No & $-0.70(-1.90-1.20)$ & & & & \\
\hline
\end{tabular}

Wallis tests, PLWHA: People with HIVIAIDS.

\section{Discussion}

\section{overview \\ Characteristics of respondents research}

The average age of nurses is at the young adult age who are mainly in the workforce [24]. The trend of having more female nurses is in line with previous studies [25], as well as in other countries. The minimum education level of health workers in this study is D3 or Diploma in Nursing [26]. There are four levels of nursing education in Indonesia, ranging from diploma, bachelor, and master to the doctorate degree. Diploma education (D3 and D4) is a nursing education which focusing more to prepare basic nursing skills, while Bachelor (S1) involving not only nursing skills but also in developing and managing nursing plan for patients. Master's degree in nursing (S2) may or may have specialist phase focuses in advance nursing practice, while the doctorate degree focuses on developing certain science studies [27].

\section{Attitude of nurses toward PwDs}

This study obtained the median score of nurses' attitudes as measured by the 19 items ATDP-Form $\mathrm{O}$ was 54 (min-max $=29-87$ ). The attitude score in this study was lower than in some earlier studies [11], [21]. The lower the score means that the respondents think PwDs are different in a negative sense. If the respondent is a non-disabled person and perceives people with a different disability, it means that it is prejudice. If the respondent is a PwDs, then the PwDs perceives themselves as different from non-disabled people. The negative attitudes of nurses are in line with the existence of stigma, discrimination, and differences in the treatment of PwDs in Indonesia [28], [29], [30], [31]. Stigma arises from negative attitudes and wrong assumptions about disabilities; stigma is an attribute that considers someone unwanted or discredits a group [32].

The median score of nurses' knowledge as measured by the SAQ-K 23 items was 19 (min$\max =5-23$ ). Nurses' knowledge score in this study was slightly higher than other published results [21]. While there are 2 items that are arguable in this instrument, namely, item 13 and 14, we can conclude that the knowledge of the nurses in this study relatively higher than the average. These two items related to how people with mild and moderate intellectual disabilities need support in planning and managing life as well as managing finances [33]. Due to various conditions of disability, people with severe disabilities or Profound and Intellectual Multiple Disabilities depend on other people [34].

This study also found that there is a positive correlation between attitude and knowledge $(p=0.033)$. Knowledge of disabilities has a positive impact on attitudes [35], [36], [37], creates awareness about disabilities [36], [37], and prevents discriminatory behavior [35]. In this study, based on the range of the questionnaire scores, the nurses' attitude score toward PwDs tended to be low. This may be because there are other factors that contribute more than nurses' knowledge and the SAQ-K instrument needs further development.

The age variable did not have a significant difference in attitude scores $(p=0.730)$. These results are compatible with previous studies [21], [38] which not found the correlation between age and attitudes of PwDs. However, age was found to be negatively correlated with the attitudes of health-care providers [39] and students [36] in other studies. This might due to shifts in perspectives and how PwDs are increasingly 
accepted culturally [39], as well as the influence of experience, training, and perceptions of PwDs [36].

Gender did not have a significant correlation with attitude scores in the study $(p=0.490)$. This result is similar to the prior studies [21], [38], [40], [41] that did not show the significant difference of attitudes toward PwDs based on their gender. There were similarities in the median knowledge score between male and female nurses in this recent study. However, the results of a study in Nepal showed that female respondents had lower attitude scores [39]. Perhaps, there may be other potential factors that may contribute to attitude scores, such as frequency of contact as showed by previous research that a higher average attitude on the participants could be occurred due to having a higher frequency of contact with PwDs [41].

The education level variable had a statistically significant disparity in scores $(p=0.042)$. Statistically, there are differences in attitudes toward PwDs between groups D3 and S1 ( $p=0.048)$, between groups D3 and S2 $(p=0.032)$, also groups D4 and $S 2(p=0.039)$. Individuals with higher levels of education have more positive attitudes toward PwDs [42], [43], [44] and tend to understand that disability does not necessarily mean completely disabled [42]. The higher education of the nurses, the more awareness of PwDs that they learn during their degree. The improvement of knowledge and awareness toward this population could positively affect their attitudes toward PwDs [45].

The variable of family history of PwDs did not have a significant difference in attitude scores $(p=0.176)$. These results are similar to previous research on student attitudes [16]. Other studies have shown that individuals with families with disabilities tend to have positive attitudes [46], [47], [48]. However, in Bhutan, negative attitudes are shown to individuals with friends/relatives of PwDs due to the lack of social support for PwDs [49]. Family relationships are influenced by culture and values [16]

In Indonesia, many families of someone with disabilities still hide family members with disabilities [50]. Indonesian society tends to have a negative perception of PwDs [51], especially people with psychosocial disabilities [52]. The majority of PwDs are unable to develop themselves and their abilities due to the lack of social support from the community and available social rehabilitation [53]. In fact, the government has made regulations regarding PwDs in Law No. 8 of 2016 as a form of the government's seriousness on the issue of disability in Indonesia [54]. This law contains rules for the obligations and rights obtained by PwDs in their scope of life. However, there are still shortcomings and limitations in the implementation of the law.

The history of interaction with PwDs has significant differences in attitude's scores statistically $(p=0.000)$. In this study, the majority of nurses have never interacted with PwDs (70.2\%). In fact, the quality of contact with PwDs is the dominant factor in influencing the attitude scores [10]. Nevertheless, a more positive attitude does not guarantee a better interaction with PwDs [35]. In addition, other studies also showed that contact with PwDs does not have a significant impact on nurses' attitudes [40].

There is also a statistical difference in the caring experience for PwDs with the attitude scores ( $p=0.001$ ). Only $29.5 \%$ of the participants have ever cared for PwDs. These results are analogous with the previous studies [36]. In general, having experience in caring for $\mathrm{PwDs}$ is related to having a positive attitude about PwDs [55].

Finally, even though educational training on disabilities is important to develop more positive attitudes [7], [11], [40], [56], participants who had a previous education/special training did not have a statistically significant difference in their attitude scores in this study $(p=0.841)$. These results are consistent with previous studies [39]. However, this may be because only a very few respondents in this study who had participated in the education/training in disabilities.

\section{Attitudes of nurses toward PWD}

In general, nurses' attitudes score as measured using the DAS questionnaire was 102 (Min-Max =60-136). In line with the previous study, this attitude score is relatively high indicating that nurses have a good attitude towards PWD [18]. The statistical analysis showed that there was a positive correlation between knowledge and attitudes of nurses toward PWD ( $p=0.000)$. Nurses with a higher knowledge score showed a better attitude toward PWD [57]. The previous study also showed that the older group of nurses tends to have a better knowledge of PWD [58]. In addition, this study showed that age has a positive correlation with attitude scores $(p=0.005)$. Individuals with older age tend to reflect a realistic attitude toward PWD since they are more aware of persistent depressive disorder (dysthymia) associated with dementia [58].

The family history with members diagnosed with dementia had a significant difference in attitude scores ( $p=0.013$ ). Having a family member with dementia predicts a more positive attitude toward dementia and a fair to moderate understanding of dementia based on participants' own judgment [59]. Individuals with a family history of PWD are less likely to exhibit stigmas such as fear and avoidance; instead they can show empathy for PWD [60].

In this study, the experience of interacting with PWD had a significant difference in attitude scores $(p=0.000)$ which is in line with previous [61]. The experience in caring for PWD has a significant difference in attitude score $(p=0.000)$. Taking care of PWD can reduce the stigma against PWD [12]. Moreover, experience of hospital staffs' (doctors, 
nurses, health-care attendants, allied professionals, and general support staff personnel) in caring for PWD contributes to a more positive attitude [59].

The prior participation in education/training about dementia had a significant difference in attitude scores $(p=0.000)$. This willingness to receive dementia education/training is a significant predictor of the DAS score in the previous study [62]. Nurses who attended special dementia training had a more positive attitude $(p=0.040)$ and an improved satisfaction in caring for PWD [63]. However, special training about dementia for nurses in Indonesia was still very scarce [64].

\section{Attitudes of nurses toward PLWHA}

The median score of the attitude in this study was -0.65 indicated that nurses tend to have negative or non-therapeutic attitudes toward PLWHA. Using the same instrument, the score for the attitude of nurses in this study was higher compared to research in the United States with a mean value of -3.18 [19]. However, it is lower when compared to the attitude score of nurses in China (mean value 0.47) [65]. Nurses have a negative attitude since they are afraid of contracting HIVIAIDS and there is a social stigma against PLWHA [66]. Fear might decrease the care for PLWHA, so that nurses feel apathetic and tend to avoid PLWHA [67].

There is a positive correlation between attitudes and knowledge scores in this recent study $(p=0.000)$. This positive correlation was supported by other studies that showed nurses who have good knowledge tend to have good attitudes [65], [68], [69].

The results of the analysis exemplify that there was a positive correlation between the attitude score and age ( $p=0.007)$. Older nurses tend to have better attitudes towards PLWHA than younger nurses [70]. Older nurses might more experience in taking care of PWLHA throughout their careers which allows them to have a better attitude towards PWLHA [69]. In contrast, other studies have shown that young people have a more positive attitude [71]. Older nurses have more negative attitudes due to lack of actual information, lack of professional promotion, and fear of infection while caring for patients [71].

There was no significant difference among gender in attitude scores $(p=0.454)$. Still, the different results indicate that male nurses tended to have a more positive attitude than female nurses [69]. Furthermore, there was no statistically significant difference between the level of education and the attitudes of nurses $(p=0.078)$. These results are consistent with research in China [65].

The interaction with PLWHA had a significant difference in attitude scores $(p=0.003)$. Previous interaction with PLWHA may influence nurses' attitudes toward PLWHA [64]. Interactions can include sitting with PLWHA, communicating and having direct physical contact [72]. Nurses who have a rather negative attitude feel that contact with PLWHA should be avoided [66]. This might because nurses feel they can get HIV if they are maintaining a close contact with them [66].

This study showed that experience in caring for PLWH had significant differences in attitude scores $(p=0.050)$. Nurses who have experienced caring for PLWHA have better attitudes [66], [71]. Nurses who have provided care for PLWHA for a long time show a more positive attitude toward PLWHA due to gaining more experience and knowledge [69].

The special education/training about HIV/ AIDS had a significant difference in attitude scores $(p=0.011)$. Nurses who have attended special HIV/ AIDS training have better attitudes [69], [70]. HIVIAIDS special education/training can improve nurses' attitudes and reduce nurses' fear of caring for PLWHA [73]. Special training/education on HIVIAIDS prevention can create a positive attitude for nurses [74]. Nurses can be given workshops on actual information on HIVIAIDS, and skills in interacting with PLWHA [75].

\section{Research limitations}

There were some changes in this research due to COVID-19 pandemic. The data collection manner moved to online which prolong the research ethical clearance and permits process in the hospital. Furthermore, online version might affect the appearance of the instrument on different devices. However, these changes were relatively minor that may not affect the overall result of the study.

\section{Conclusions}

In this study, the score of nurses' attitudes toward PwDs, PWD, and PLWHA tends to be lower than similar studies. Knowledge, interaction history, and experience of caring have a significant effect on nurses' attitudes toward vulnerable people. The level of education generally only affects the attitudes of nurses towards PwDs. Family history overall only affects nurses' attitudes toward PWD. Remarkably, the age and special education/training only affect the attitudes of nurses toward PWD and PLWHA.

\section{Suggestions}

This study can serve as an evaluation for health services to initiate programs to increase the knowledge and experience of nurses in caring for 
vulnerable people. This needs to be done in order to improve the quality of nursing services. Future study can conduct further qualitative research related to nurses' experiences in caring for vulnerable people in terms of difficulties, feelings, and psychosocial skills to further understand nurses' attitudes and avoid stigma against vulnerable people.

\section{Acknowledgement}

The researchers would like to thank to the Faculty of Medicine, Public Health, and Nursing, Universitas Gadjah Mada, Indonesia for funding this research as well as the respondent who willing to participate in this study.

\section{References}

1. National Collaborating Centre for Determinants of Health. Vulnerable Population. Nova Scotia: National Collaborating Centre for Determinants of Health; 2020. Available from: https:// www.nccdh.ca/glossary/entry/vulnerable-populations. [Last accessed on 2020 Apr 01].

2. Salem BE, Nyamathi A, Phillips LR, Mentes J, Sarkisian C, Brecht L. Identifying frailty among vulnerable populations. NIH Public Access. 2014;37(1):70-81. https://doi.org/10.1097/ ans. 0000000000000013

PMid:24469090

3. World Health Organization. Disability and Health; 2018. Available from: https://www.who.int/news-room/fact-sheets/ detail/disability-and-health. [Last accessed on 2020 Dec 01].

4. World Health Organization. Dementia. Geneva: World Health Organization; 2019. Available from: https://www.who.int/ news-room/fact-sheets/detail/dementia. [Last accessed on 2020 Dec 10].

5. UNAIDS. HIV and AIDS-basic Facts; 2020. Available from: https://www.unaids.org/en/frequently-asked-questions-abouthiv-and-aids. [Last accessed on 2020 Dec 29].

6. Waisel DB. Vulnerable populations in healthcare. Curr Opin Anaesthesiol. 2013;26(2):186-92.

PMid:23385323

7. Lewis S, Stenfert-Kroese B. An investigation of nursing staff attitudes and emotional reactions towards patients with intellectual disability in a general hospital setting. J Appl Res Intellect Disabil. 2010;23(4):355-65. https://doi. org/10.1111/j.1468-3148.2009.00542.x

8. Fajarwaty ND. Hubungan Persepsi Klien Tentang Kualitas Pelayanan Kesehatan dengan Tingkat Kepuasan Pasien dalam Pemenuhan Kebutuhan Dasar di Pusat Rehabilitasi Penyandang Cacat. Yogyakarta: Sekolah Tinggi Ilmu Kesehatan' Aisyiyah Yogyakarta; 2012. Available from: http://www.digilib. unisayogya.ac.id. [Last accessed on 2020 Dec 15]. https://doi. org/10.36729/jam.v4i1.229

9. Allen $\mathrm{H}$, Wright $\mathrm{BJ}$, Harding $\mathrm{K}$, Broffman $\mathrm{L}$. The role of stigma in access to health care for the poor. Milbank Q. 2014;92(2):289318. https://doi.org/10.1111/1468-0009.12059

\section{PMid:24890249}

10. Au KW, Man DW. Attitudes toward people with disabilities: A comparison between health care professionals and students. Int J Rehabil Res. 2006;29(2):155-60. https://doi.org/10.1097/01. mrr.0000210048.09668.ab

PMid:16609328

11. Matziou V, Galanis P, Tsoumakas C, Gymnopoulou E, Perdikaris $\mathrm{P}$, Brokalaki $\mathrm{H}$. Attitudes of nurse professionals and nursing students towards children with disabilities. Do nurses really overcome children's physical and mental handicaps? Int Nurs Rev. 2009;56(4):456-60. https://doi. org/10.1111/j.1466-7657.2009.00735.x

12. Strøm BS, Engedal K, Andreassen L. Nursing staff's knowledge and attitudes toward dementia: A pilot study from an Indian perspective. Dement Geriatr Cogn Dis Extra. 2019;9:352-61. https://doi.org/10.1159/000502770

13. Harapan H, Khalilullah SA, Anwar S, Zia M, Novianty F, Putra RP, et al. Discriminatory attitudes toward people living with HIV among health care workers in Aceh, Indonesia: A vista from a very low HIV caseload region. Clin Epidemiol Glob Health. 2015;3(1):29-36. https://doi.org/10.1016/j.cegh.2013.08.001

14. Waluyo A, Nova PA, Edison C. Perilaku Perawat terhadap Orang dengan HIVIAIDS di Rumah Sakit dan Puskesmas. J Keperawatan Indones. 2011;14(2):127-32. https://doi. org/10.7454/jki.v14i2.320

15. Yuker HE, Block JR, Young JH. The Measurement of Attitudes Towards Disabled Persons. New York: INA Mend Institute; 1970.

16. Syarifa NO. Gambaran Sikap Mahasiswa Keperawatan Terhadap Penyandang Disabilitas di PSIK FK-KMK UGM. Indonesia: Universitas Gadjah Mada; 2020.

17. O'Connor ML, Mcfadden SH. Development and psychometric validation of the dementia attitudes scale. Int J Alzheimers Dis. 2010;2010:1-11.

18. Aisy Sunaryo SR, Saifullah AD, Mulyani S. Knowledge and attitudes toward people with dementia among nursing students in Yogyakarta, Indonesia. Belitung Nurs J. 2020;6(6):196-202. https://doi.org/10.33546/bnj.1178

19. FromanRD, OwenSV. Furthervalidation oftheAIDS attitudescale. Res Nurs Health. 1997;20(2):161-7. https://doi.org/10.1002/ (sici)1098-240x(199704)20:2<161:aid-nur8>3.0.co;2-i PMid:9100746

20. Wahyuningtias R. Gambaran Pengetahuan dan Sikap Mahasiswa Keperawatan Terhadap Orang dengan HIVIAIDS Beserta Faktor-Faktornya di PSIK FK-KMK UGM. Indonesia: Universitas Gadjah Mada; 2020. https://doi.org/10.35814/ mindset.v8i02.324

21. Iftikhar K, Alamgir A, Maqbool S, Rehan W, Akhtar S. Knowledge and attitude of health care professionals towards person with disability. Pak Armed Forces Med J. 2019;69(1):147-53.

22. Annear MJ, Toye C, Elliott KJ, Mcinerney F, Eccleston C Robinson A. Dementia knowledge assessment scale (DKAS): Confirmatory factor analysis and comparative subscale scores among an international cohort. BMC Geriatr. 2017;17(1):168. https://doi.org/10.1186/s12877-017-0552-y PMid:28760154

23. Carey MP, Schroder KE. Development and psychometric evaluation of the brief HIV knowledge questionnaire. NIH Public Access. 2002;14(2):172-82. https://doi.org/10.1521/ aeap.14.2.172.23902

PMid:12000234

24. Ratanto R, Mustikasari M, Kuntarti K. Pengembangan karier sebagai faktor paling memengaruhi kinerja Perawat Pelaksana J Keperawatan Indones. 2013;16(2):114-9. https://doi. org/10.7454/jki.v16i2.10

25. Rusnawati NR. Relasi Gender dalam Tugas-Tugas Keperawatan di Rumah Sakit Puri Husada Sleman Yogyakarta. Yogyakarta: 
Universitas Negeri Yogyakarta; 2012. https://doi.org/10.31227/ osf.io/8vsr5

26. Presiden Republik Indonesia. Undang-Undang Republik Indonesia Nomor 36 Tahun 2014 Tentang Tenaga Kesehatan 36 Indonesia. Indonesia: Presiden Republik Indonesia; 2014. https://doi.org/10.29313/aktualita.v2i1.4659

27. Indonesia PR. Undang-Undang Republik Indonesia Nomor 20 Tahun 2003 tentang Sistem Pendidikan Nasional 20 Indonesia. Indonesia: Presiden Republik Indonesia; 2003. https://doi. org/10.30649/phj.v18i2.164

28. Anisa A. Difabel dan kesempatan kerja: Penanggulangan diskriminasi dalam dunia kerja melalui pendekatan pekerjaan sosial. J Pengemb Masy Islam. 2019;5(2):121-40. https://doi. org/10.32678/lbrmasy.v5i02.2169

29. Lestari EY, Sumarto S, Isdaryanto N. Pemenuhan hak bagi penyandang disabilitas di kabupaten semarang melalui implementasi convention on the rights of persons with disabillities (CRPD) dalam Bidang Pendidikan. Integralistik. 2017;1:1-9. https://doi.org/10.15294/integralistik.v33i1.28731

30. Ndaumanu F. Hak penyandang disabilitas: Antara tanggung jawab dan pelaksanaan oleh pemerintah Daerah. J HAM. 2020;11(1):131-50. https://doi.org/10.30641/ ham.2020.11.131-150

31. Yusainy C, Thohari S, Gustomy R. StopAbleism: Reduksi stigma kepada penyandang disabilitas melalui intervensi bias implisit. J Psikol. 2016;43(1):1. https://doi.org/10.22146/jpsi.9168

32. Division for Social Policy and Development. Culture, Beliefs, and Disability. Toolkit On Disability For Africa. Africa: Division for Social Policy and Development; 2017. p. 1-32.

33. The Centre for Development Disability Health Victoria. Working with People with Intellectual Disabilities in Healthcare Settings. United Kingdom: The Centre for Development Disability Health Victoria; 2014. p. 1-6. Available from: http://www.cddh.org. [Last accessed on 2020 Dec 10].

34. Wehmeyer ML. Handbook of Positive Psychology and Disability. New York: Oxford University Press; 2013. https://doi. org/10.1093/oxfordhb/9780195398786.001.0001

35. Olaoye O, Oduola B, Alonge T, Emechete A. Attitude towards, contact with people with disabilities and knowledge of disability among health science undergraduates in a Nigerian university. J Behav Health. 2017;6(3):1. https://doi.org/10.5455/ jbh.20170401112757

36. Uysal A, Albayrak B, Koçulu B, Kan F, Aydin T. Attitudes of nursing students toward people with disabilities. Nurse Educ Today. 2014;34(5):878-84. https://doi.org/10.1016/j.nedt.2013.09.001 PMid:24080269

37. SahinH,AkyolAD.Evaluationofnursingandmedicalstudents'attitudes towards people with disabilities. J Clin Nurs. 2010;19(15-16):2271-9. https://doi.org/10.1111/j.1365-2702.2009.03088.x PMid:20522157

38. Al Adwan MA. Attitudes and emotional responses of the nurses in Jordanian public hospitals toward caring for patients with disabilities. Lupine Online J Nurs Health Care. 2018;1(1):26-30. https://doi.org/10.32474/lojnhc.2018.01.000105

39. Devkota HR, Murray E, Kett M, Groce N. Healthcare provider's attitude towards disability and experience of women with disabilities in the use of maternal healthcare service in rural Nepal. Reprod Health. 2017;14(1):1-14. https://doi.org/10.1186/ s12978-017-0330-5

40. Velonaki VS, Kampouroglou G, Velonaki M, Dimakopoulou K, Sourtzi P, Kalokerinou A. Nurses' knowledge, attitudes and behavior toward Deaf patients. Disabil Health J. 2015;8(1):109-17. https://doi.org/10.1016/j.dhjo.2014.08.005

41. Ruiz PO, Gonzalez-Medina G, Couso AS, Palomares MJ, Mansilla JR, Ardila EM, et al. Attitude towards people with disability of nursing and physiotherapy students. Children.
2020;7(10):191. https://doi.org/10.3390/children7100191 PMid:33092027

42. Agyemang $C B$, Delle E. Demographic factors and attitude toward disable employees: Empirical evidence from Ghana. Res Humanit Soc Sci. 2013;3(19):53-60.

43. Morin D, Rivard M, Crocker AG, Boursier CP, Caron J. Public attitudes towards intellectual disability: A multidimensional perspective. J Intellect Disabil Res. 2013;57(3):279-92. https:// doi.org/10.1111/jir.12008

PMid:23279318

44. Page SL, Islam MR. The role of personality variables in predicting attitudes toward people with intellectual disability: An Australian perspective. J Intellect Disabil Res. 2015;59(8):741-5. https:// doi.org/10.1111/jir.12180

PMid:25559160

45. Polikandrioti M, Govina O, Vasilopoulos G, TheodoulaA, Plakas S, Kalemikerakis I, et al. Nursing students' attitudes towards people with disabilities. Int J Caring Sci. 2020;13(1):480-8.

46. Klooster PM Ten, Dannenberg JW, Taal E, Burger G, Rasker JJ. Attitudes towards people with physical or intellectual disabilities: Nursing students and non-nursing peers. J Adv Nurs. 2009;65(12):2562-73.

PMid: 19941543

47. Huskin PR, Reiser-Robbins C, Kwon S. Attitudes of undergraduate students toward persons with disabilities: Exploring effects of contact experience on social distance across ten disability types. Rehabil Couns Bull. 2018;62(1):53-63. https://doi.org/10.1177/0034355217727600

48. Yorke AM, Ruediger T, Voltenburg N. Doctor of physical therapy students' attitudes towards people with disabilities: A descriptive study. Disabil Rehabil. 2017;39(1):91-7. https://doi.org/10.3109/ 09638288.2016.1140830

PMid:26883300

49. Dorji S, Solomon P. Attitudes of health professionals toward persons with disabilities in Bhutan. Asia Pac Disabil Rehabil J. 2009;20(2):32-42.

50. Kementerian Kesehatan Republik Indonesia. Situas penyandang disabilitas. In: Aprianda R, Ismandari F, editors. Buletin Jendela Data dan Informasi Kesehatan. Jakarta: Kementerian Kesehatan Republik Indonesia; 2014. https://doi. org/10.14203/press.298

51. Widinarsih D. Penyandang disabilitas di Indonesia: Perkembangan istilah dan definisi. J IImu Kesejahteraan Sosial. 2019;20(2):127-42.

52. Hastuti, Dewi RK, Pramana RP, Sadaly H. In: Sarahtika DP, Hadiz L, editors. Kendala Mewujudkan Pembangunan Inklusif terhadap Penyandang Disabilitas. Jakarta: The SMERU Research Institute; 2020. Available from: https://www.smeru. or.id. [Last accessed on 2020 Dec 17].

53. Naibaho $M$, Krisnani $H$, Nuriyah E. Program rehabilitasi sosia bagi penyadang disabilitas di panti sosial bina daksa budi perkasa Palembang. Pros Penelit dan Pengabdi Kpd Masy. 2015;2(3):331-40. https://doi.org/10.24198/jppm.v2i3.13580

54. Hanjarwati A, Suprihatiningrum J, Aminah S. Persepsi penyandang disabilitas dan stakeholder untuk mempromosikan dan mengembangkan komunitas inklusif di DIY dan Sulawesi Tenggara. Sosiol Reflekt. 2019;13(2):379-404. https://doi. org/10.14421/jsr.v13i12.1625

55. Satchidanand N, Gunukula SK, Lam WY, McGuigan D, New I, Symons AB, et al. Attitudes of healthcare students and professionals toward patients with physical disability: Asystematic review. Am J Phys Med Rehabil. 2012;91(6):533-45. https://doi.org/10.1097/phm.0b013e3182555ea4 PMid:22596075

56. Cervasio K, Fatata-Hall K. Attitudes of nurses toward children 
with disabilities: The attitudes of nursing students toward children with disabilities: An experimental design. Int J Phys Med Rehabil. 2013;1(5):1-15. https://doi.org/10.4172/2329-9096.1000140

57. Afolabi AO, Eboiyehi FA, Afolayan KA. Gender analysis of nurses' attitude towards care of the elderly with dementia in Obafemi Awolowo university teaching hospitals complex, lleIfe, Osun State, Nigeria. J Women Aging. 2019;32(2):203-19. https://doi.org/10.1080/08952841.2019.1682488

PMid:31793390

58. Mulyani S, Artanti ER, Saifullah AD. Knowledge and attitudes towards people with dementia among general population in Yogyakarta. Adv Health Sci Res. 2019;15:230-5. https://doi org/10.2991/icosihsn-19.2019.50

59. Keogh B, To WT, Daly L, Hynes G, Kennelly S, Lawlor B, et al. Acute hospital staff' $s$ attitudes towards dementia and perceived dementia knowledge: A cross-sectional survey in Ireland. BMC Geriatr. 2020;20(376):376. https://doi.org/10.1186/ s12877-020-01783-6 PMid:32998718

60. Chang $\mathrm{CY}$, Hsu HC. Relationship between knowledge and types of attitudes towards people living with dementia. Int J Environ Res Public Health. 2020;17(11):3777. https://doi.org/10.3390/ ijerph17113777 PMid:32466533

61. Blaser R, Berset J. Setting matters: Associations of nurses attitudes towards people with dementia. Nurs Open. 2019;6(1):155-61. https://doi.org/10.1002/nop2.198 PMid:30534405

62. Zhao W, Moyle W, Petsky H. Hospital healthcare professionals knowledge of dementia and attitudes towards dementia care: A cross-sectional study. J Clin Nurs. 2020. https://doi. org/10.1111/jocn.15590

PMid:33295010

63. Evripidou M, Charalambous A, Middleton N, Papastavrou E. Nurses' knowledge and attitudes about dementia care: Systematic literature review. Perspect Psychiatr Care. 2018;55(1):48-60. https://doi.org/10.1111/ppc.12291 PMid:29766513

64. Mulyani S, Probosuseno, Nurjannah I. The effect of training on dementia care among nurses : A systematic review. Maced J Med Sci. 2021;9:145-52. https://doi.org/10.3889/oamjms.2021.5969

65. Li L, Yinglan L, Kai Z, Ying W. Knowledge and Attitudes to HIVIAIDS in Chinese Registered Nurse. J Cent South Univ. 2011;36(2):121-7.

PMid:21368420

66. Hassan ZM, Wahsheh MA. Knowledge and attitudes of
Jordanian nurses towards patients with HIVIAIDS: Findings from a nationwide survey. Issues Ment Health Nurs. 2011;32(12):774-84. https://doi.org/10.3109/01612840.201 1.610562 PMid:22077750

67. Husna C, Fitriani I. Kompetensi Perawat Pelaksana dalam Merawat Pasien HIVIAIDS. Idea Nurs J. 2016;7(1):70-8.

68. Paul M. Health literacy: Investigating the knowledge and attitudes of HIVIAIDS among students in Southern Ethiopia. Health Tomorrow. 2014;2:1-19.

69. Vorasane S, Jimba M, Kikuchi K, Yasuoka J, Nanishi K, Durham $\mathrm{J}$, et al. An investigation of stigmatizing attitudes towards people living with HIVIAIDS by doctors and nurses in Vientiane, Lao PDR. BMC Health Serv Res. 2017;17(125):1-13. https://doi.org/10.1186/s12913-017-2068-8

PMid:28183300

70. Waluyo A, Culbert GJ, Levy J, Norr K. Understanding HIV-related stigma among Indonesian nurses. J Assoc Nurses AIDS Care. 2015;26(1):69-80. https://doi.org/10.1016/j.jana.2014.03.001 PMid:24759060

71. Vallejos IC, Sánchez HE, Lagunas LF, Valdés BC, Acosta RC. Knowledge, attitudes and perceptions of nurses and nursing students towards HIVIAIDS. Invest Educ Enferm. 2010;28(3):345-54.

PMid:27499563

72. Mahamboro DB, Fauk NK, Ward PR, Merry MS, Siri TA, Mwanri L. HIV Stigma and moral judgement: Qualitative exploration of the experiences of HIV stigma and discrimination among married men living with HIV in Yogyakarta. Int J Environ Res Public Health. 2020;17(2):1-15. https://doi.org/10.3390/ijerph17020636 PMid:31963807

73. Famoroti TO, Fernandes L, Chima SC. Stigmatization of people living with HIVIAIDS by healthcare workers at a tertiary hospital in KwaZulu-Natal, South Africa: A cross-sectional descriptive study. BMC Med Ethics. 2013;14 Suppl 1:1-10. https://doi. org/10.1186/1472-6939-14-s1-s6 PMid:24564982

74. Aryanto SD, Rahmat I, Kustanti A. Pengetahuan dan Stigma Perawat terkait Orang dengan HIVIAIDS (ODHA). J Persat Perawat Nas Indones. 2018;3(2):98-110. https://doi. org/10.32419/jppni.v3i2.107

75. Okpala PU, Uwak R, Nwaneri AC, Onyiapat J, Emesowum A, Osuala EO, et al. Nurses' knowledge and attitude to the care of HIVIAIDS patients in South East, Nigeria. Int J Community Med Public Health. 2017;4(2):547. https://doi.org/10.18203/23946040.ijcmph20170289 